\title{
Effects of Dietary Propionate and Heat Exposure on Glucose Disappearance Rate and Insulin Secretion in Sheep
}

\author{
Hiroaki Sano*, Sang Rak LeE, Fujimi Yamazaki, Mario Orlandi*, \\ Yasuyuki SASAKI and Tsuneyuki TsUdA ${ }^{* * *}$ \\ Faculty of Agriculture, Tohoku University, Sendai-shi 980 \\ * Faculty of Animal Science, Kitasato University, Towada-shi 034 \\ ${ }^{* *}$ Faculty of Veterinary Medicine, Pisa University, Pisa, Italy \\ *** Tokyo University of Agriculture, Setagaya-ku, Tokyo 156
}

(Received February 22, 1988)

\begin{abstract}
Sheep were fed lucerne hay alone or supplemented with a physiological dose of calcium propionate $(10 \mathrm{mmol} / \mathrm{kg} \mathrm{BW})$ and exposed to a thermoneutral $\left(20^{\circ} \mathrm{C}\right)$ or a hot environment $\left(30^{\circ} \mathrm{C}\right)$ in order to observe the effects of dietary propionate and of heat exposure on glucose disappearance rate and insulin response following the intravenous injection of glucose.

The blood glucose disappearance rate before feeding tended to be higher for lucerne hay with the calcium propionate diet than for the lucerne hay alone diet, but the blood glucose disappearance rate after feeding tended to be lower for lucerne hay with the calcium propionate diet than for the lucerne hay alone diet. Insulin secretion in response to glucose injection before feeding tended to be greater during heat exposure than under the thermoneutral condition regardless of diet, and after feeding it tended to be smaller for the lucerne hay with calcium propionate diet than for the lucerne hay alone diet, regardless of air temperature. These results suggest that both the rate of blood glucose utilization and insulin secretory response to exogenous glucose are influenced more by dietary conditions than by environmental heat exposure.

Jpn. J. Zootech. Sci., 59 (12) : 1019-1026, 1988
\end{abstract}

Key words: insulin, propionic acid, glucose disappearance rate, heat exposure, sheep

Blood glucose metabolism is known to be influenced by nutritional, physiological and environmental conditions ${ }^{1-3}$. Blood glucose turnover rate measured by the isotope dilution method decreased during heat exposure in shorn sheep ${ }^{3}$. The rumen concentration of propionic acid, one of the major glucogenic substrates, was reported to decrease markedly during heat exposure ${ }^{4)}$. Therefore, dietary supplementation of propionic acid may improve the decreased blood glucose turnover rate during heat exposure.

Insulin is one of the important hormones controlling carbohydrate metabolism in both ruminant and non-ruminant animals. The insulin secretory response to glucose injection is reported to be altered by cold exposure ${ }^{5)}$, fatness ${ }^{6)}$, stage of lactation $^{7)}$ and feeding ${ }^{8)}$ in ruminants. However, little attention has been focused on the insulin 
response to glucose injection during heat exposure. Our previous report showed that insulin response to feeding was accelerated in sheep fed lucerne hay with a physiological level of calcium propionate $(10 \mathrm{mmol} / \mathrm{kg}$ body weight $(\mathrm{BW}))$ both in thermoneutral and heat exposure conditions ${ }^{9)}$.

The objective of this experiment was to measure glucose disappearance rates and insulin responses following glucose injection in sheep which were fed the high propionate diet and exposed to heat.

\section{Materials and Methods}

\section{Animals}

Six crossbred (Suffolk $\times$ Corriedale) shorn sheep were used, aged from 2 to $3 \mathrm{yrs,}$ weighing 24 to $44 \mathrm{~kg}$. They were surgically prepared with a skin loop enclosing the left carotid artery and a rumen cannula under anesthesia with pentobalbitone sodium (25 $\mathrm{mg} / \mathrm{kg} \mathrm{BW}$ ) at least one month before the experiment started. Animals were kept in metabolic cages in a controlled environment chamber at an air temperature of 18$22^{\circ} \mathrm{C}$ for more than a week before the experiment. Other animal treatments were almost the same as described previously ${ }^{9}$. Each sheep received the following four treatments : (1) $20 \mathrm{~L}$ : lucerne hay cube alone diet (fed at a level of $20 \mathrm{~g} / \mathrm{kg} \mathrm{BW} /$ day) in a thermoneutral environment $\left(20^{\circ} \mathrm{C}\right)$; (2) $20 \mathrm{P}$ : lucerne hay cube $(16 \mathrm{~g} / \mathrm{kg} \mathrm{BW} /$ day $)$ plus calcium propionate $(10 \mathrm{mmol} / \mathrm{kg} \mathrm{BW} /$ day) diet in a thermoneutral environment ; (3) $30 \mathrm{~L}$ : lucerne hay cube alone diet in a hot environment $\left(30^{\circ} \mathrm{C}\right)$; (4) $30 \mathrm{P}$ : lucerne hay cube plus calcium propionate diet in a hot environment. Each treatment lasted for 2 weeks and the sequence of treatments was incompletely randomized. The lucerne hay cubes contained $8800 \mathrm{~kJ}$ digestible energy and $109 \mathrm{~g}$ crude protein per kilogram. The animals were fed these diets almost isoenergically at $12: 00$ for $2 \mathrm{hrs}$, and water was given at $12: 00$ for $6 \mathrm{hrs}$. Other aspects of animal management were the same as described previously ${ }^{9}$.

\section{Experimental procedures}

The experiments were carried out on days 11 and 14 of each treatment. Polyethylene catheters were inserted into the jugular vein at least 5 days in advance and into the skin loop of the carotid artery at least $2 \mathrm{hrs}$ before the experiment commenced.

Glucose $(0.625 \mathrm{mmol} / \mathrm{kg}$ BW, $2.5 \mathrm{M}$ solution) was injected through the jugular catheter for $1 \mathrm{~min}$ at $2 \mathrm{hrs}$ before or $2 \mathrm{hrs}$ after feeding on different experimental days (day 11 or 14) for each treatment. Blood samples $(5 \mathrm{ml})$ were taken from the carotid catheter at $-10,-5,0,5,10,15,30,45,60$ and $90 \mathrm{~min}$, and rumen samples $(10 \mathrm{ml})$ were taken through the rumen cannula at 0,45 and $90 \mathrm{~min}$ after glucose injection. Blood and rumen samples were centrifuged in the cold $\left(4^{\circ} \mathrm{C}\right)$ at $10,000 \times g$ for $10 \mathrm{~min}$ and the supernatants of blood and rumen fluids were stored at $-25^{\circ} \mathrm{C}$ until analysis. Analysis

Concentrations of glucose and insulin in plasma and volatile fatty acids (VFA) in the rumen fluid were measured as described previously ${ }^{9}$. The concentration of calcium 
in the rumen was determined by using a Calcium test kit (Wako, Osaka) ${ }^{10}$. Calculations

The glucose disappearance rate was calculated from the incremental concentrations of plasma glucose at 15,30 and $45 \mathrm{~min}$ after glucose injection ${ }^{8}$. The insulin area, which was the incremental area under the curve above the initial level for insulin concentrations in response to glucose, was calculated over $90 \mathrm{~min}$ after glucose injection. The significance of differences was evaluated via the Student's paired $t$-test which was used to compare preinjection means with values obtained after glucose injection and also to test the effects of the timing of glucose injection. Analysis of variance and $\mathrm{F}$-test were used for comparisons between the treatments.

\section{Results and Discussion}

\section{Physiological responses}

Physiological responses, feed intake and water intake have been reported previously $^{9}$. Feed intake was less $(P<0.01)$ for the lucerne hay with calcium propionate diet $(0.50$ and $0.47 \mathrm{~kg} /$ day for $20 \mathrm{P}$ and $30 \mathrm{P})$ than for the lucerne hay alone diet $(0.65$ and $0.67 \mathrm{~kg} / \mathrm{day}$ for $20 \mathrm{~L}$ and $30 \mathrm{~L})$, although the diet amounts offered to the sheep were less for the lucerne hay with calcium propionate diet than for the lucerne hay alone diet because these diets were offered isoenergically in the present experiment. The lucerne hay with calcium propionate diet might not have been palatable for sheep. Rumen fluid

Table 1. Effects of dietary calcium propionate and heat exposure $\left(30^{\circ} \mathrm{C}\right)$ on concentrations of total VFA, acetic acid, propionic acid, butyric acid and calcium in the rumen

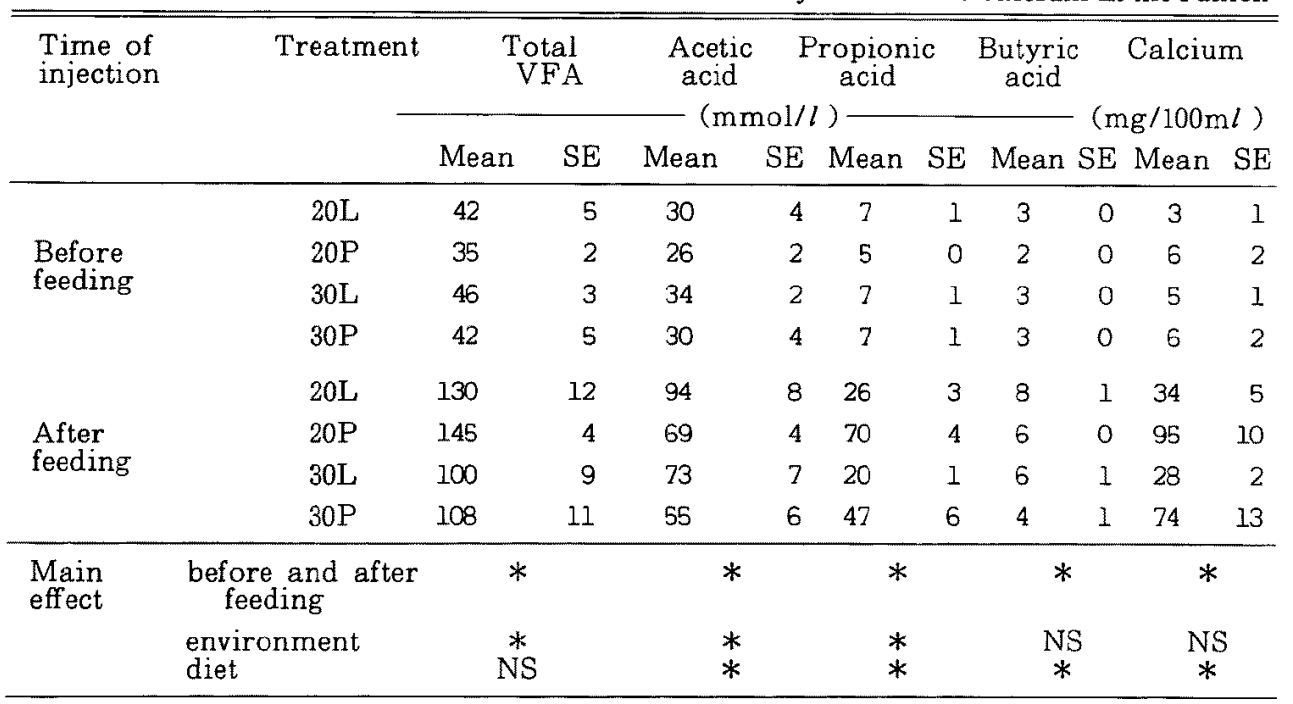

Mean values are presented, averaged over the three sampling times

$(0,45$ and $90 \mathrm{~min}$ after glucose injection).

* $: P<0.05$

NS : not significant

20 : a thermoneutral environment $\left(20^{\circ} \mathrm{C}\right), 30:$ a hot environment $\left(30^{\circ} \mathrm{C}\right), \mathrm{L}:$ lucerne hay alone diet, $\mathrm{P}$ : lucerne hay with calcium propionate diet 
Sano, Lee, Yamazaki, Orlandi, Sasaki and Tsuda

Concentrations of calcium, total VFA and individual VFAs in the rumen during the experiment are given in Table 1. All concentrations were similar between treatments before feeding, but were much higher $(P<0.05)$ after feeding than before feeding. Concentrations of propionic acid and calcium in the rumen after feeding were much higher $(P<0.05)$ for the lucerne hay with calcium propionate diet than for the lucerne hay alone diet. Concentrations of acetic acid in the rumen were lower for the lucerne hay with calcium propionate diet than for the lucerne hay alone diet. Concentrations of total VFA in the rumen did not differ between the diets. The concentrations of propionic acid in the rumen after feeding were within the physiological range ${ }^{11)}$ in the present experiment.

The concentrations of total VFA, acetic acid and propionic acid in the rumen after feeding were lower $(P<0.05)$ during heat exposure than under the thermoneutral condition : nevertheless, feed intake did not differ between the environments $(0.65$, $0.50,0.67$ and $0.47 \mathrm{~kg} /$ day for $20 \mathrm{~L}, 20 \mathrm{P}, 30 \mathrm{~L}$ and $30 \mathrm{P}$, respectively). The concentrations of butyric acid and calcium in the rumen tended to be lower during heat exposure than under the thermoneutral condition. These results may correlate with the increase in water intake during heat exposure.

Plasma constituents

Baseline concentrations of plasma glucose were similar between treatments before feeding (50.6, 46.9, 48.2 and $50.9 \mathrm{mg} / 100 \mathrm{ml}$ for $20 \mathrm{~L}, 20 \mathrm{P}, 30 \mathrm{~L}$ and $30 \mathrm{P}$, respectively), but tended to be higher for the lucerne hay with calcium propionate diet (51.9 and $50.1 \mathrm{mg} / 100 \mathrm{ml}$ for $20 \mathrm{P}$ and $30 \mathrm{P}$ ) than for the lucerne hay alone diet (44.8 and $48.6 \mathrm{mg} / 100 \mathrm{~m} l$ for $20 \mathrm{~L}$ and $30 \mathrm{~L}$ ) after feeding (Fig. 1). Concentrations of plasma glucose after the intravenous injection of $0.625 \mathrm{mmol} / \mathrm{kg} \mathrm{BW}$ of glucose increased $(P<0.01)$ rapidly, reaching a peak $(91.7-104.4 \mathrm{mg} / 100 \mathrm{ml})$ at $5 \mathrm{~min}$ after glucose injection and decreasing gradually thereafter in all of the experiments. The extent of hyperglycemia induced by glucose injection was similar between treatments. The plasma glucose concentration before feeding almost returned to the initial values by $90 \mathrm{~min}$ after glucose injection. The blood glucose disappearance rate before feeding tended to be higher for the lucerne hay with calcium propionate diet than for the lucerne hay alone diet, regardless of environmental temperature (Table 2). However, the feed treatments and environmental conditions in the present experiment did not significantly affect the blood glucose disappearance rate. The elevated plasma glucose concentration after glucose injection decreased slower after feeding than before feeding. Plasma glucose concentrations after feeding still remained higher at $90 \mathrm{~min}$ after glucose injection than the initial levels, the differences from the initial values being $10.4,9.3,11.1$ and $12.9 \mathrm{mg} / 100 \mathrm{ml}$ for $20 \mathrm{~L}, 20 \mathrm{P}, 30 \mathrm{~L}$ and $30 \mathrm{P}$, respectively. Furthermore, the elevated plasma glucose concentrations after glucose injection decreased slower for the lucerne hay with calcium propionate diet than for the lucerne hay alone diet after feeding. The glucose disappearance rate also tended to be lower for the lucerne hay with calcium propionate diet than for the lucerne hay alone diet after feeding. Insulin action to glucose utilization may be reduced when large 

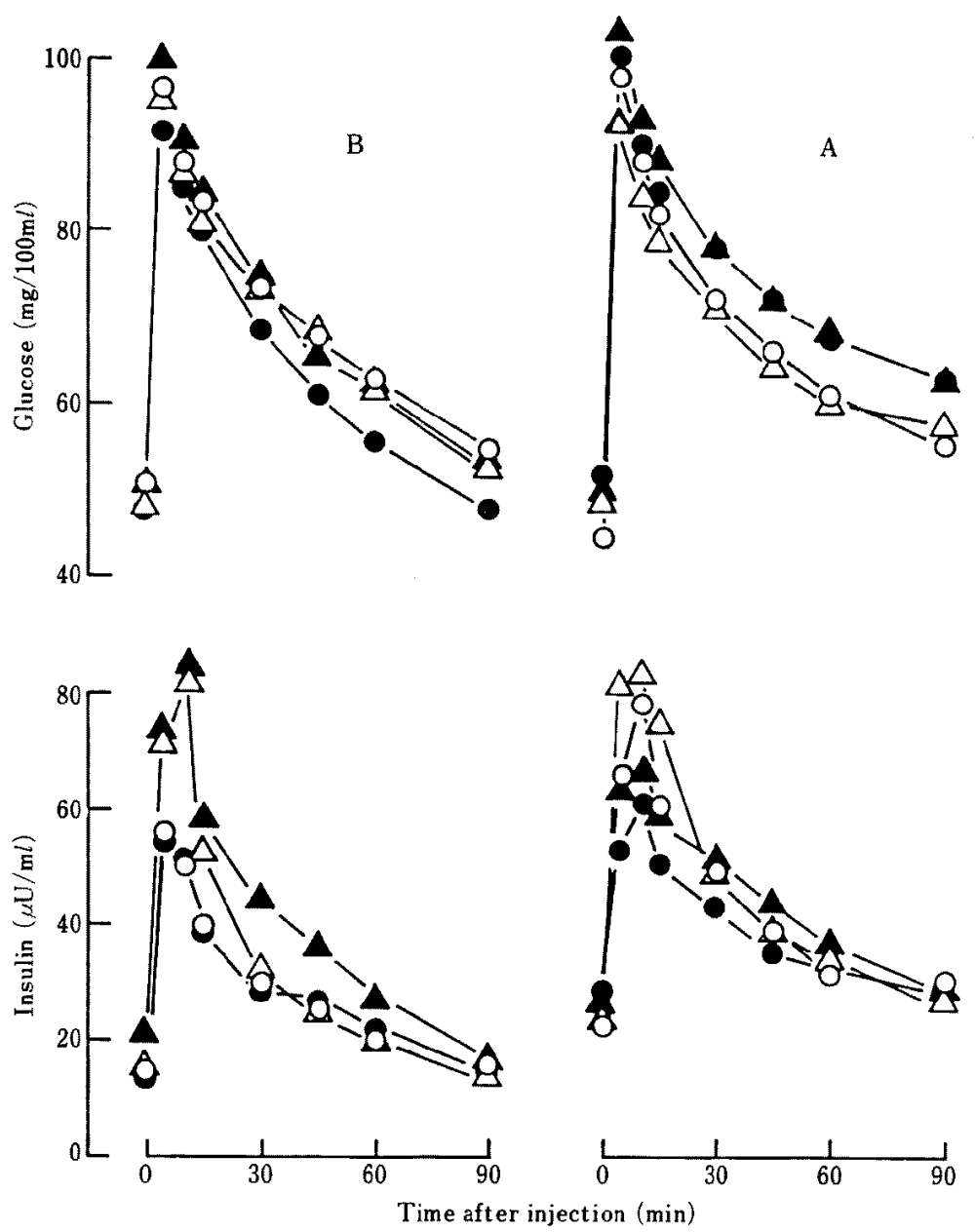

Fig. 1. Effects of dietary calcium propionate and heat exposure $\left(30^{\circ} \mathrm{C}\right)$ on plasma glucose and insulin in response to intravenous injection of glucose $(0.625 \mathrm{mmol} / \mathrm{kg} \mathrm{BW})$ at $2 \mathrm{hrs}$ before feeding (B) and $2 \mathrm{hrs}$ after feeding (A) in sheep. The treatments were as follows: $20 \mathrm{~L}$ : lucerne hay alone diet in a thermoneutral environment $(O)$; $20 \mathrm{P}$ : lucerne hay with calcium propionate diet in a thermoneutral environment (O) ; $30 \mathrm{~L}$ : lucerne hay alone diet in a hot environment $(\Delta) ; 30 \mathrm{P}$ : lucerne hay with calcium propionate diet in a hot environment $(\boldsymbol{\Delta})$.

amounts of nutrients containing insulinotropic substrates are absorbed from the digestive tracts, especially in the case of the lucerne hay with calcium propionate diet.

Concerning the glucose disappearance rate of the injected glucose, no significant differences were observed between the treatments or between the timing of glucose injections in the present experiment. A more sensitive parameter of glucose metabolism, the blood glucose turnover rate, was not measured simultaneously in the present study. The glucose disappearance rate for the lucerne hay alone diet did not differ between before and after feeding, but for the lucerne hay with calcium propionate diet it tended to be lower after feeding than before feeding. KaTz and 
Table 2. Effects of dietary calcium propionate and heat exposure $\left(30^{\circ} \mathrm{C}\right)$ on insulin area* and glucose disappearance rate following glucose injection in sheep

\begin{tabular}{|c|c|c|c|c|c|}
\hline $\begin{array}{l}\text { Timing of } \\
\text { injection }\end{array}$ & Treatment & \multicolumn{2}{|c|}{$\begin{array}{c}\text { Glucose } \\
\text { disappearance rate } \\
(\not / \mathrm{min}) \\
\text { Mean } \mathrm{SE}\end{array}$} & \multicolumn{2}{|c|}{$\begin{array}{c}\text { Insulin area } \\
(\mathrm{mU} / \mathrm{ml} \cdot 90 \mathrm{~min}) \\
\text { Mean }\end{array}$} \\
\hline \multirow{4}{*}{$\begin{array}{l}\text { Before } \\
\text { feeding }\end{array}$} & $20 \mathrm{~L}$ & 2.4 & 0.4 & 1.1 & 0.3 \\
\hline & $20 \mathrm{P}$ & 3.0 & 0.4 & 1.2 & 0.3 \\
\hline & $30 \mathrm{~L}$ & 1.8 & 0.4 & 1.5 & 0.4 \\
\hline & $30 \mathrm{P}$ & 3.0 & 0.8 & 1.6 & 0.5 \\
\hline \multirow{4}{*}{$\begin{array}{l}\text { After } \\
\text { feeding }\end{array}$} & $20 \mathrm{~L}$ & 2.1 & 0.5 & 1.9 & 0.3 \\
\hline & $20 \mathrm{P}$ & 1.7 & 0.4 & 0.9 & 0.3 \\
\hline & $30 \mathrm{~L}$ & 2.4 & 0.7 & 2.0 & 0.5 \\
\hline & $30 \mathrm{P}$ & 1.8 & 0.1 & 1.6 & 0.3 \\
\hline
\end{tabular}

* Insulin area is the incremental area above the initial level over $90 \mathrm{~min}$ after glucose injection.

20 : a thermoneutral environment $\left(20^{\circ} \mathrm{C}\right)$,

30 : a hot environment $\left(30^{\circ} \mathrm{C}\right)$,

$\mathrm{L}:$ lucerne hay alone diet,

$\mathrm{P}$ : lucerne hay with calcium propionate diet

BERGMAN ${ }^{12)}$ demonstrated that hepatic glucose production in sheep increased after feeding. SASAKI et al. ${ }^{8)}$ also reported that the glucose disappearance rate in sheep was much higher during a meal. As far as the present experiment is concerned, however, it is likely that the glucose disappearance rate of injected glucose is not a very sensitive index of blood glucose metabolism, especially when exogenous glucogenic substrates are supplied additively to the diet. Therefore, there was no exact indication of whether the decreased blood glucose turnover rate during heat exposure was improved by the propionate supplementation or not.

Baseline concentrations of plasma insulin tended to be higher after feeding (22.4, 28.6, 23.7 and $27.1 \mu \mathrm{U} / \mathrm{m} l$ for $20 \mathrm{~L}, 20 \mathrm{P}, 30 \mathrm{~L}$ and $30 \mathrm{P}$, respectively) than before feeding $(14.9,14.0,15.6$ and $21.3 \mu \mathrm{U} / \mathrm{m} l$ for $20 \mathrm{~L}, 20 \mathrm{P}, 30 \mathrm{~L}$ and $30 \mathrm{P}$, respectively), and also tended to be higher during heat exposure than under the thermoneutral condition (Fig. 1). Plasma insulin responded significantly $(P<0.05)$ to the intravenous injection of glucose $(0.625 \mathrm{mmol} / \mathrm{kg} \mathrm{BW})$ for all treatments. The peak concentrations of plasma insulin before feeding tended to be higher during heat exposure $(82.5$ and $84.0 \mu \mathrm{U} / \mathrm{ml}$ at $10 \mathrm{~min}$ for $30 \mathrm{~L}$ and $30 \mathrm{P}$ ) than under the thermoneutral condition (55.3 and $54.2 \mu \mathrm{U} / \mathrm{m} l$ at $5 \mathrm{~min}$ for $20 \mathrm{~L}$ and $20 \mathrm{P}$ ), regardless of the diet. The insulin area before feeding also tended to be larger during heat exposure than under the thermoneutral condition (Table 2). It was observed that insulin concentration during the initial stage after feeding tended to be greater during heat exposure than under the thermoneutral condition in sheep fed a diet of lucerne hay alone ${ }^{9)}$. However, DenBow et $a l .^{7)}$ reported that both the baseline insulin concentrations and the magnitude of the insulin response to glucose in cattle were higher in spring than in summer. They suggested that lower insulin during summer was due to the result of decreased VFA. 
VFA levels in the rumen before feeding, which did not differ between the treatments in the present experiment, may explain a part of this inconsistency.

The peak insulin concentrations induced by glucose injection after feeding tended to be lower for the lucerne hay with calcium propionate diet $(60.6$ and $66.6 \mu \mathrm{U} / \mathrm{m} l$ for $20 \mathrm{P}$ and $30 \mathrm{P})$ than for the lucerne hay alone diet $(77.9$ and $83.7 \mu \mathrm{U} / \mathrm{m} l$ for $20 \mathrm{~L}$ and $30 \mathrm{~L}$ ). The insulin area after feeding also tended to be smaller for the lucerne hay with calcium propionate diet than for the lucerne hay alone diet. It was observed that insulin levels, which had reached a peak, decreased gradually in sheep fed the lucerne hay with calcium propionate $(10 \mathrm{mmol} / \mathrm{kg} \mathrm{BW} /$ day) even though propionic acid in the rumen still remained at a high level. WEEKEs ${ }^{13)}$ administered a primed infusion of a VFA mixture into the rumen of sheep for $6 \mathrm{hrs}$ and found a similar result. He suggested that the trigger for insulin secretion might be a change in the level of propionate rather than the absolute level of propionate (personal communication). It is concluded that a greater supply of insulinotropic substrates in the diet decreases the insulin responsiveness to glucose regardless of air temperature.

\section{Acknowledgements}

The authors are most grateful to Dr. T.E.C. WEEkES, Univesity of Newcastle, for his kind advice on the manuscript. This study was supported in part by Japan Society for the Promotion of Science as postdoctoral fellow.

\section{References}

1) Bergman, E.N., Cornell Vet., 63: 341-382. 1973.

2) WeEkes, T.E.C., Y. SASAKr and T. Tsuda, Am. J. Physiol., 244: E 335-E 345. 1983.

3) Sano, H., K. Takahashi, K. Ambo and T. Tsuda, J. Dairy Sci., 66 : 856-861. 1983.

4) Kelley, R.O., F.A. Maftz and H.D. Johnson, J. Dairy Sci., 50 : 531-533. 1968.

5) Sasaki, Y. and H. Takahashi, J. Physiol., $306: 323-335.1980$.

6) McCann, J.P., M.B. Ullmann, M.R. Temple, T.J. Reimers and E.N. Bergman, J. Nutr., 116 : 1287-1297. 1986.

7) Denbow, C.J., K.S. Perera, F.C. Gwazdauskas, R.M. Akers, P.E. Pearson and M.L. MCGilliard, J. Dairy Sci., 69 : 211-216. 1986.

8) Sasaki, Y., H. Takahashi, H. Aso, K. Hikosaka, A. Hagino and S. Oda, Br. J. Nutr., 52 : 351-358. 1984.

9) Sano, H., S.R. Lee, F. Sato, M. Orlandi, Y. Sasaki and T. Tsuda, Jpn. J. Zootech. Sci., 58 : 1086-1094. 1987.

10) Conerty, H.V. and A.R. Briggs, Am. J. Clin. Path., 45 : 290-296. 1966.

11) WeEkes, T.E.C. and A.J.F. Webster, Br. J. Nutr., 33 : 425-438. 1975.

12) Katz, M.L. and E.N. Bergman, Am. J. Physiol., 216 : 953-960. 1960.

13) WEeKes, T.E.C., J. Physiol., $254: 80$ P-81 P. 1976. 
Sano, Lee, Yamazaki, OrLandi, Sasaki and Tsuda

\title{
めん羊におけるグルコース消失速度およびインスリン分泌に対する 飼料中プロピオン酸および暑熱の影響
}

\author{
佐野宏明*・李 相洛・山崎ふじみ・M. ORLANDI ${ }^{* *}$ \\ 佐々木康之・津田恒之 ${ }^{* * *}$ \\ 東北大学農学部, 仙台市 980 \\ * 北里大学獣医畜産学部, 十和田市 034 \\ **ピサ大学獣医学部, ピサ,イタリア \\ *** 東京農業大学, 東京都世田谷区 156
}

グルコースの静脈注入後のグルコース消失速度および
インスリン分泌反心に対する飼料中プロピオン酸および
暑熱の影響を明らかにするために, めん羊にアルファル
ファへイキューブ単一飼料あるいはアルファルファヘイ
キューブに生理的レベルのプロピオン酸カルシゥム $(10$
$\mathrm{mmol} / \mathrm{kg} \mathrm{BW})$ を添加した飼料（高プロピオン酸飼料）
を給与し，常温 $\left(20^{\circ} \mathrm{C}\right)$ あるいは暑熱 $\left(30^{\circ} \mathrm{C}\right)$ に暴露し
た.
血液グルコース消失速度は採食前にはアルファルファ ヘイキューブ単一飼料より䯩プロピオン酸飼料の方が
高い傾向を示したが，採食後には低い傾向を示した。 グルコース注入に対するインスリン分泌反応は採食前に は飼料に関係なく常温時よりる暑熱時の方が大きい傾向 を示し，採食後には環境温度に関係なくアルファルファ ヘイキューブ箸一飼料より高プロピオン酸飼料の方か 小さい傾问を示した．これらの結果から血液グルコース の利用速度および外因性グルコースに対するインスリン 分泌反応はとむに暑熱暴露よりあむしろ飼料条件に影響 されると考えられた。

日畜会報, $59(12): 1019-1026,1988$ 